\title{
Ovarian sex cord-stromal tumours: an update in recent molecular advances
}

\author{
DiANA Lim ${ }^{1,2}$ AND EsTher OLIVA ${ }^{3}$ \\ ${ }^{1}$ Department of Pathology, National University Hospital, Singapore; ${ }^{2}$ Translational Centre \\ for Development and Research, National University Health System, Singapore; and \\ ${ }^{3}$ Department of Pathology, Massachusetts General Hospital, Boston, MA, United States
}

\begin{abstract}
Summary
Sex cord-stromal tumours (SCSTs) consist of a heterogeneous group of neoplasms with diverse clinicopathological features and biological behaviour. They often present as a diagnostic challenge as they have varied and occasionally overlapping histomorphology and some may even mimic non-SCSTs. An accurate diagnosis is important for therapeutic and prognostic purposes. The use of a panel of immunohistochemical markers which are sensitive and specific for sex cord-stromal differentiation such as $\alpha$-inhibin, calretinin, SF-1 and FOXL2, may be helpful in confirming the cellular lineage of these tumours, but is of limited utility in distinguishing between the different tumour types within this category. Additionally, the development of new therapeutic strategies in patients with SCSTs is also hampered by the infrequent occurrence of these neoplasms.

Recent molecular analyses of some SCSTs has led to the discovery of novel molecular events, which may have important diagnostic, prognostic and therapeutic implications. The salient pathological features, management issues and recently described genetic aberrations in adult and juvenile granulosa cell tumours as well as SertoliLeydig cell tumours are discussed in this review, with particular emphasis on the clinical significance of FOXL2 and DICER1 mutations. An in-depth understanding of the molecular pathogenesis underlying SCSTs may aid in improving tumour classification and disease prognostication and also potentially lead to the discovery of more effective treatment strategies.
\end{abstract}

Key words: Sex cord-stromal; FOXL2; DICER1; immunohistochemistry; molecular; ovary.

Received 8 August, accepted 17 October 2017

Available online 21 December 2017

\section{INTRODUCTION}

Sex cord-stromal tumours (SCSTs) are a diverse group of neoplasms derived from either gonadal sex cord cells (granulosa and sertoli cells), gonadal stromal cells (theca cells), or fibroblasts. ${ }^{1}$ They account for $8 \%$ of all primary ovarian tumours and encompass entities with widely varied clinicopathological features and biological behaviour. In the most recent World Health Organization (WHO) classification of tumours of the female reproductive organs, SCSTs are separated into pure stromal, pure sex cord and mixed SCSTs ${ }^{2}$ (Table 1). Whilst most tumours have characteristic morphological appearance, some can exhibit unusual or overlapping features and even mimic non-SCSTs. In these instances, ancillary techniques, such as immunohistochemistry may be useful in confirming the cellular lineage of these tumours. Most SCSTs express $\alpha$-inhibin, calretinin and steroidogenic factor-1 (SF-1) and are typically negative for epithelial and germ cell tumour markers. More recently, FOXL2 (Foxhead box protein L2) has also been identified to be a sensitive and specific marker of sex cord-stromal differentiation. However, no immunomarker shows absolute sensitivity or specificity for SCSTs and most have limited utility in distinguishing between the different tumour types within this category.

Recent studies have led to the discovery of novel molecular events, which may have important diagnostic, prognostic and therapeutic implications in this group of tumours. In this review, we discuss the salient pathological features, management issues and recently described genetic aberrations in granulosa cell and Sertoli-Leydig cell tumours, and examine the clinical significance of these molecular findings.

\section{GRANULOSA CELL TUMOURS}

Granulosa cell tumours represent $90 \%$ of all ovarian SCSTs and constitute $\sim 5 \%$ of ovarian cancers. They are divided into two categories: adult GCTs (AGCTs) and juvenile GCTs (JGCTs) on the basis of differing clinicopathological characteristics. Evidence provided by various molecular studies also indicates that these tumours are distinct entities.

\section{Adult granulosa cell tumours}

AGCTs constitute $95 \%$ of all granulosa cell tumours and are the most common malignant SCSTs. ${ }^{3,4}$ They can occur at any age but are commonly seen in perimenopausal or early postmenopausal women with a peak age incidence between 50 and 55 years. ${ }^{5}$ Patients often present with oestrogenic manifestations such as menometrorrhagia or post-menopausal bleeding and some may have underlying endometrial hyperplasia and/or adenocarcinoma. Rarely, AGCT can be associated with androgenic manifestations, especially if they are cystic. ${ }^{6}$ Patients may also present with abdominal pain and distension secondary to a large pelvic mass.

The majority $(90 \%)$ of tumours are unilateral with an average diameter of $12 \mathrm{~cm}$, although size may vary from microscopic to $\sim 30 \mathrm{~cm}$. Cut surface typically reveals a tan (Fig. 1A) to yellowish solid or solid-cystic appearance, but 
Table 1 WHO classification of ovarian sex cord-stromal tumours

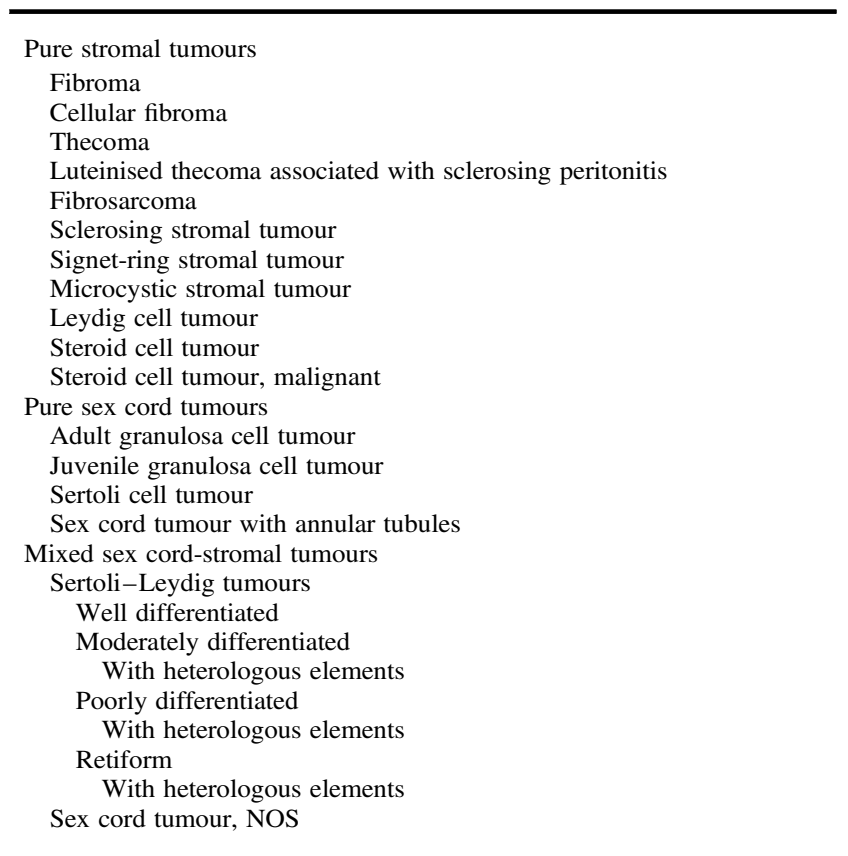

NOS, not otherwise specified; WHO, World Health Organization.

rarely, tumours may be predominantly cystic. On microscopic examination, AGCTs can exhibit a wide spectrum of morphological features, with a combination of growth patterns often encountered within the same tumour. The granulosa cells have ovoid or round nuclei, pale chromatin and often, nuclear grooves, imparting a 'coffee-bean' appearance (Fig. 1B). The cytoplasm is usually scant, although luteinised cells with moderate to abundant eosinophilic cytoplasm, round to ovoid nuclei with prominent nucleoli and lacking nuclear grooves may be seen. ${ }^{7,8}$ Mitotic rate is variable but generally low $(<5 / 10 \mathrm{HPF})$. Bizarre cells may be identified in $\sim 2 \%$ of $\mathrm{AGCTs}^{9}$ and rare tumours with sarcomatous transformation $^{10}$ or hepatic differentiation ${ }^{11}$ have been reported. Cells can be arranged in a variety of architectural patterns including diffuse or sheet-like growth, microfollicular, macrofollicular, trabecular, insular, tubular (solid or hollow), corded, watered silk and gyriform (zigzag cords). Call-Exner bodies (Fig. 1C) are a feature of the microfollicular pattern, and are characterised by microcystic spaces containing eosinophilic basal lamina material. The presence of nuclear grooves and Call-Exner bodies are often considered to be pathognomonic of AGCTs, however these features may be lacking in some tumours and their absence does not preclude a diagnosis of AGCT.

\section{Chromosomal aberrations}

Using cytogenetic ${ }^{12}$ and comparative genomic hybridisation analyses, ${ }^{13}$ trisomy of chromosomes 12 and 14 and monosomy of chromosome 22 have been detected in a subset of AGCTs. ${ }^{12,13}$ Caburet et al. also reported the presence of supernumerary chromosomes $8,9,12$ and 14 as well as partial or complete loss of chromosomes 1p, 13p, 16, 11 and 22, with a statistically significant non-random association for +14 with -22 and +7 with $-16 q .{ }^{14}$

\section{FOXL2}

In a landmark study using whole-transcriptome sequencing, Shah et al. identified a recurrent, somatic missense mutation in codon $134(402 \mathrm{C} \rightarrow \mathrm{G})$ of FOXL2 (Fig. 2) in four AGCTs. ${ }^{15}$ This mutation was also identified in $86 / 89(97 \%)$ additional AGCTs, but only in 3/14 (21\%) thecomas and 1/10 $(10 \%)$ JGCTs, and none of the 49 ovarian SCSTs of other types, 149 epithelial ovarian tumours and 180 breast carcinomas. It has since been postulated that this mutation is the driver event in AGCTs. ${ }^{15}$

FOXL2 is a single-exon gene of $2.7 \mathrm{~kb}$ located at $3 \mathrm{q} 23$ that encodes for a 376 amino acid protein, which is a member of the forkhead-winged helix family of transcription factors containing a highly conserved DNA-binding forkhead domain. FOXL2 is selectively expressed in the mesenchyme of developing mouse eyelids and in the adult ovarian follicle. It is one of the earliest markers of ovarian differentiation, and is essential for the normal development of granulosa cells. ${ }^{16,17}$ FOXL2 has also been linked to the regulation of several key biological processes, such as apoptosis, oxidative stress response and cell proliferation. Several targets of FOXL2 have been identified in gonadal cells ${ }^{18}$ including genes fundamental to granulosa cell function and the development of ovarian follicles. ${ }^{19}$ Regulation of gene expression by FOXL2 involves interactions with other transcription factors such as nuclear receptors and the SMAD family of transcription factors. ${ }^{20,21}$

Germline mutations in FOXL2 result in the blepharophimosis, ptosis, and epicanthus inversus syndrome (BPES), either with or without associated premature ovarian failure. $^{22}$ The somatic missense point mutation (C402G)

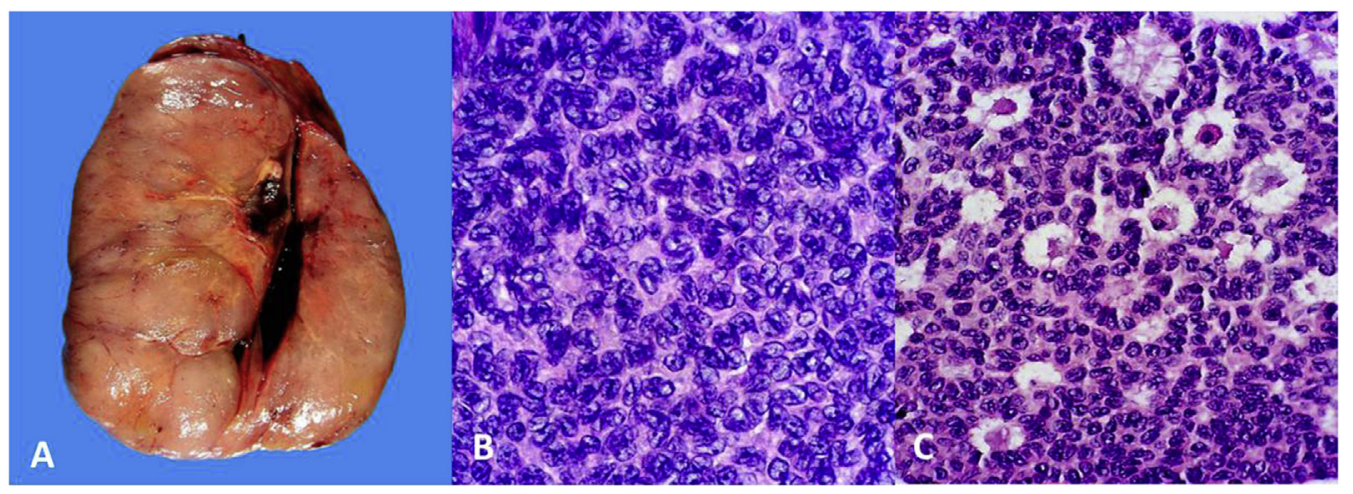

Fig. 1 Adult granulosa cell tumour. (A) The tumour is solid with a tan cut surface. (B) The cells have ovoid nuclei and longitudinal nuclear grooves. (C) Call-Exner bodies are noted. 
associated with AGCTs, leads to the substitution of a highly conserved cysteine residue by tryptophan $(\mathrm{C} 134 \mathrm{~W})$, although this does not appear to affect either function or localisation of the protein. ${ }^{15}$ This mutation is seen in the heterozygous state in most tumours, however the exact mechanism by which the C134W mutation in FOXL2 contributes to tumourigenesis of granulosa cells remain unresolved. In vitro studies suggest that dysregulated FOXL2 function may alter cell cycle progression, steroidogenesis, apoptosis and even DNA damage repair in granulosa cells. ${ }^{23-25}$ Gene expression studies have also shown that AGCTs are significantly enriched for known FOXL2 target genes, affirming the importance of this mutation in these tumours.

Using single-strand conformation polymorphism analysis, Kim et al. showed that 53/56 (94.6\%) AGCTs harboured the FOXL2 p.C134W mutation. ${ }^{27}$ Similarly, other investigators have identified FOXL2 mutations in $61-95 \%$ of ovarian AGCTs. ${ }^{27-36}$ Nolan et al. also identified FOXL2 mutations in $6 / 12$ granulosa theca cell tumours (ovarian SCSTs that have between $10 \%$ and $50 \%$ of granulosa cells in a prominent fibrothecomatous background), and the authors noted that tumours with higher content of granulosa cells as well as those in which the granulosa cells formed large lobules were more likely to harbour the mutation. ${ }^{37}$ Interestingly, a small number of testicular AGCTs have also been found to habour this aberration. Lima et al. identified FOXL2 mutation in 2/5 (40\%) AGCTs but not in nine other testicular tumours (1 JGCT, 5 Leydig cell tumours and 3 SLCTs). ${ }^{38}$

In addition to AGCTs, FOXL2 mutations have been reported in only $7 / 45(15 \%)$ thecomas, $2 / 59(3.4 \%)$ JGCTs and 5/63 $(8 \%)$ SLCTs. ${ }^{15,27,29,39}$ This mutation has not been demonstrated in other ovarian SCSTs such as fibromas, gynandroblastomas, sex-cord tumours with annular tubules, sclerosing stromal tumours, microcystic stromal tumours, steroid cell tumours; germ cell tumours, epithelial or mesenchymal tumours. $15,27-31,33,34,39-44$ Table 2 summarises the results from various studies evaluating FOXL2 mutation status in different subtypes of ovarian tumours. Of note, some thecomas harbouring the mutation were reclassified as AGCTs on review, ${ }^{45}$ while reappraisal of some AGCTs lacking the mutation suggests that they may have been misclassified initially. ${ }^{30}$ However, the presence of bona fide AGCTs lacking FOXL2

\section{FOXL2}

\section{p.C134W $($ c. $402 C>G)$}

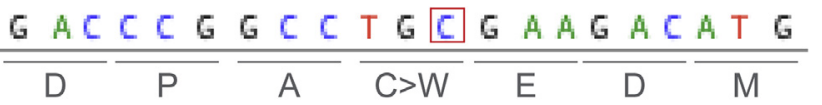

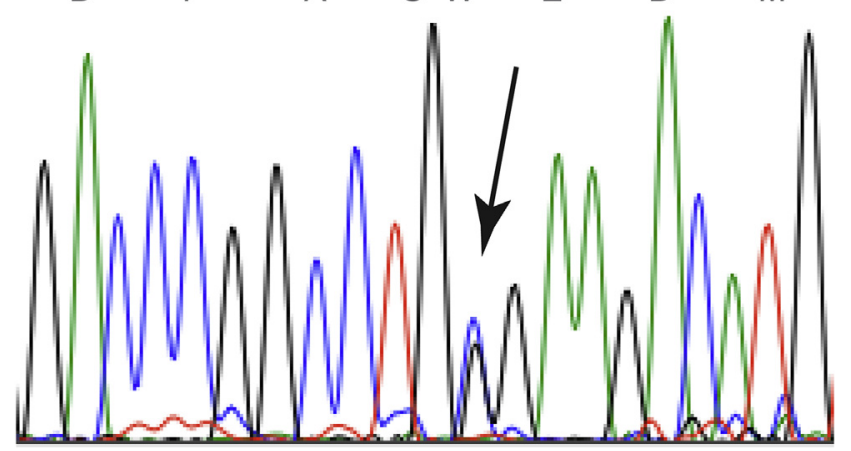

Fig. 2 Adult granulosa cell tumour with c. $402 \mathrm{C}>\mathrm{G}$ mutation of the FOXL2 gene (arrow). (Figure courtesy of Dr Britta Weigelt.) mutations, albeit rare, also indicates that it is plausible that other molecular events can result in a morphological AGCT phenotype. ${ }^{15}$

Overall, it appears that FOXL2 mutation is a sensitive and specific biomarker for AGCTs which can be employed in a diagnostic setting to help resolve problematic cases. Additionally, one group of investigators was able to detect the FOXL2 mutation in circulating tumour DNA from a subset of patients with AGCTs, demonstrating that a molecular diagnosis of AGCTs and detection of tumour recurrences can also be achieved through non-invasive methods. ${ }^{46}$

\section{Immunohistochemical profile}

Alpha-inhibin, calretinin (Fig. 3) and SF-1 are sensitive markers of AGCTs. ${ }^{47-53}$ Compared to $\alpha$-inhibin, calretinin is a more sensitive but less specific marker of sex cord-stromal differentiation. ${ }^{51} \mathrm{SF}-1$ is expressed in both adult and juvenile granulosa cell tumours and studies have reported that the sensitivity of SF-1 for granulosa cell tumours is $100 \% .^{47,53}$ However, SF-1 can also be expressed by other SCSTs, ${ }^{33,54}$ limiting its use in distinguishing AGCTs from other tumour types in this category. Additionally, AGCTs can exhibit immunoreactivity for vimentin, CD99 and WT-1. ${ }^{55,56}$ In comparison to SF-1, WT-1 is less sensitive and specific for SCSTs and it is also less sensitive for granulosa cell tumours. 53,55

AGCTs can display variable positivity for CD56, AE1/3, CAM5.2, smooth muscle actin, desmin, S100, ER and PR but typically do not express CD34, CK7 or EMA. ${ }^{48,57-61}$ Areas of hepatic differentiation may be AFP, CEA, EMA and CAM5.2 positive but are vimentin and $\alpha$-inhibin negative. ${ }^{62}$

FOXL2 is a recently described immunomarker expressed in almost all adult and juvenile granulosa cell tumours. $27,28,39$ However, in contrast to the specificity of FOXL2 mutations, nuclear FOXL2 immunoexpression is seen in almost all ovarian SCSTs, including those lacking the corresponding mutation. ${ }^{27,39}$ In one study, FOXL2 immunoexpression was identified in 95/119 (80\%) SCSTs, including: 41/42 (97.6\%) AGCTs, 20/40 (50\%) SLCTs, 9/9 JGCTs, 9/9 fibromas, 5/5 sclerosing stromal tumours, $3 / 5(60 \%)$ thecomas, $3 / 3$ fibrosarcomas, 2/2 sex-cord tumours with annular tubules, 1/11 (9\%) steroid cell tumour and 3/4 (75\%) unclassified sex cord tumours. No FOXL2 immunoreactvity was detected in: Leydig cells of SLCTs, all nine retiform SLCT, all six Leydig cell tumours and all four stromal luteomas. Among all other non-SLCTs tested $(n=368)$, only three female adnexal tumours of probable Wolffian origin (FATWO) were positive for this marker. In contrast, only $38 \%$ of the SCSTs harboured FOXL2 mutations, with AGCTs accounting for the vast majority $(39 / 42,93 \%)$ of them. All except for one FOXL2 mutant tumour exhibited FOXL2 immunoreactivity. None of the non-SCST cases tested, including the three FATWOs, harboured a FOXL2 mutation. ${ }^{39}$ In this study, the authors also compared the immunoexpression of FOXL2, $\alpha$ inhibin and calretinin, in a series of 89 SCSTs. ${ }^{39}$ It was shown that FOXL2 was a more sensitive marker for SCSTs than $\alpha$-inhibin and calretinin, and immunoreactive tumours demonstrated a stronger staining pattern with FOXL2 than either $\alpha$-inhibin or calretinin. Retained immunoexpression for $\alpha$-inhibin and/or calretinin was noted in SLCTs lacking FOXL2 staining. In another study, Kim et al. ${ }^{27}$ evaluated the expression of $\alpha$-inhibin and FOXL2 in 56 AGCTs, five 
Table 2 FOXL2 mutation in ovarian and non-ovarian tumours

\begin{tabular}{|c|c|}
\hline Reference & Tumours with FOXL2 mutation \\
\hline \multirow[t]{5}{*}{ Shah et al., $2009^{15}$} & 90/93 (97\%) AGCTs \\
\hline & $1 / 10(10 \%)$ JGCTs \\
\hline & $3 / 14(21 \%)$ Thecomas \\
\hline & 0/24 (0\%) Fibromas \\
\hline & $0 / 10(0 \%)$ Steroid cells tumours \\
\hline \multirow[t]{2}{*}{ Schrader et al., $2009^{44}$} & $13 / 13(100 \%)$ AGCTs \\
\hline & $\begin{array}{l}\text { 0/725 (0\%) Epithelial and } \\
\text { mesenchymal tumours }\end{array}$ \\
\hline \multirow[t]{9}{*}{ Kim et al., $2010^{27}$} & $53 / 56(95 \%)$ AGCTs \\
\hline & $0 / 6(0 \%) \mathrm{JGCTs}$ \\
\hline & $2 / 16(12.5 \%)$ Thecomas \\
\hline & $0 / 3(0 \%)$ Fibrothecomas \\
\hline & $0 / 4(0 \%)$ SLCTs \\
\hline & $0 / 1(0 \%) 0$ SCTAT \\
\hline & $0 / 4(0 \%)$ SSTs \\
\hline & $\begin{array}{l}\text { 0/85 }(0 \%) \text { Ovarian epithelial } \\
\quad \text { carcinomas }\end{array}$ \\
\hline & $\begin{array}{l}\text { 0/1167 }(0 \%) \text { Non-ovarian } \\
\text { malignancies }\end{array}$ \\
\hline \multirow[t]{2}{*}{ Kim et al., $2010^{31}$} & $18 / 20(90 \%)$ AGCTs \\
\hline & $0 / 3(0 \%)$ JGCTs \\
\hline \multirow[t]{3}{*}{ Jamieson et al., $2010^{30}$} & $52 / 56(93 \%)$ AGCTs \\
\hline & $0 / 3(0 \%)$ JGCTs \\
\hline & $0 / 3(0 \%)$ Ovarian carcinomas \\
\hline \multirow{2}{*}{ D'Angelo et al., $2011^{28}$} & $19 / 27(70 \%)$ AGCTs \\
\hline & $0 / 18(0 \%)$ JGCTs \\
\hline \multirow{15}{*}{ Al-Agha et al., $2011^{39}$} & $39 / 42(93 \%)$ AGCTs \\
\hline & $0 / 9(0 \%)$ JGCTs \\
\hline & 0/9 (0\%) Fibromas \\
\hline & $2 / 5(40 \%)$ Thecomas \\
\hline & $0 / 5(0 \%)$ SSTs \\
\hline & $3 / 40(7 \%)$ SLCTs \\
\hline & $1 / 4(25 \%)$ SCSTs, unclassified \\
\hline & $0 / 2(0 \%)$ SCTATs \\
\hline & $0 / 11(0 \%)$ Steroid cell tumours \\
\hline & 0/6 $(0 \%)$ Ovarian germ cell tumours \\
\hline & $0 / 322(0 \%)$ Ovarian epithelial tumours \\
\hline & 0/7 (0\%) Mesenchymal tumours \\
\hline & $\begin{array}{l}\text { 0/1 }(0 \%) \text { Small cell carcinoma, } \\
\text { hypercalcaemic type }\end{array}$ \\
\hline & $0 / 3(0 \%)$ FATWO \\
\hline & $\begin{array}{l}\text { 0/30 (0\%) Metastatic epithelial } \\
\text { tumours }\end{array}$ \\
\hline \multirow[t]{3}{*}{ Oparka et al., $2012^{33}$} & $4 / 5(80 \%)$ AGCTs \\
\hline & 0/5 (0\%) Fibromas \\
\hline & $0 / 6(0 \%)$ Gynandroblastomas \\
\hline Rosario et al., $2013^{35}$ & $18 / 26(69 \%)$ AGCTs \\
\hline McCluggage et al., $2013^{42}$ & $0 / 22(0 \%)$ Cellular fibromas \\
\hline Kommoss et al., $2014^{32}$ & $40 / 41(98 \%)$ AGCTs \\
\hline \multirow{4}{*}{ Oseto et al., $2014^{34}$} & $27 / 44(61 \%)$ AGCTs \\
\hline & $0 / 2(0 \%)$ JGCTs \\
\hline & $0 / 3(0 \%)$ Germ cell tumours \\
\hline & $\begin{array}{l}\text { 0/63 }(0 \%) \text { Surface epithelial-stromal } \\
\text { tumours }\end{array}$ \\
\hline Irving et al., $2015^{41}$ & 0/14 (0\%) Microcystic stromal tumours \\
\hline Zannoni et al., $2016^{36}$ & $33 / 37(89 \%)$ AGCTs \\
\hline \multirow[t]{9}{*}{ Goulvent et al., $2016^{29}$} & 95/101 (94\%) AGCTs \\
\hline & $1 / 8(13 \%) \mathrm{JGCTs}$ \\
\hline & $2 / 19(11 \%)$ SLCTs \\
\hline & 0/10 (0\%) Fibrothecomas \\
\hline & $0 / 2(0 \%)$ Sertoli cell tumours \\
\hline & $0 / 2(0 \%)$ Steroid cell tumours \\
\hline & $0 / 1(0 \%) \mathrm{SST}$ \\
\hline & $0 / 1(0 \%)$ SCTAT \\
\hline & $0 / 12(0 \%)$ Unidifferentiated SCSTs \\
\hline Meurgey et al., $2017^{43}$ & $0 / 3(0 \%)$ Microcystic stromal tumours \\
\hline \multirow{3}{*}{ Buza et al., $2017^{40}$} & $31 / 35(89 \%)$ AGCTs \\
\hline & $1 / 4(25 \%)$ SLCTs \\
\hline & 1/11 (9\%) Fibromas/Fibrothecomas \\
\hline
\end{tabular}

AGCT, adult granulosa cell tumour; FATWO, female adnexal tumour of probable Wolffian origin; JGCT, juvenile granulosa cell tumour; SCST, sex cord-stromal tumour; SCTAT, sex cord tumour with annular tubules; SLCT, Sertoli-Leydig cell tumour; SST, sclerosing stromal tumour.
JGCTs, and two thecomas. Alpha-inhibin was expressed in 50/56 (89\%) AGCTs, 4/5 (80\%) JGCTs and both thecomas, while all the tumours in this cohort stained for FOXL2, regardless of their FOXL2 mutation status. FOXL2 immunoexpression has also been described in microcystic stromal tumours, ${ }^{43}$ which lack FOXL2 mutations. ${ }^{41,43}$

Overall, evidence indicates that while FOXL2 has limited value in differentiating between different subtypes of SLCTs, it is a relatively sensitive and highly specific marker for SCSTs and together with $\alpha$-inhibin and calretinin, constitutes an immunomarker panel that will allow for the identification of most SCSTs. A tumour lacking FOXL2, $\alpha$-inhibin and calretinin expression is highly unlikely to be a SCST and the possibility of other tumour types should be excluded. ${ }^{39}$

\section{Management and outcome}

Most patients with AGCTs present with disease confined to the ovary, although all AGCTs have a malignant potential and may develop pelvic/lower abdominal recurrences or less commonly, distant metastases. Recurrences have been reported up to 30 years after initial surgery, underpinning the importance of long-term follow-up. ${ }^{63}$ Stage is the most important prognostic factor. ${ }^{64,65}$ Patients with stage I tumours have a much better 10-year survival rate than those with advanced stage disease ( $86 \%$ versus $49 \%) ;{ }^{66}$ however, the 25 -year survival rate is considerably lower (40-60\%), due to late tumour recurrences. ${ }^{67}$

One of the major challenges in the management of patients with AGCTs lies in the identification of those at risk of developing disease recurrences. Various clinicopathological and molecular parameters such as age, tumour size $(>5 \mathrm{~cm})$, tumour rupture, incomplete tumour debulking, nuclear atypia, mitotic rate, diffuse growth, reduced $\beta$-catenin expression, expression of transcription factor GATA4 and human epidermal growth factor receptor HER2 have been reported to be associated with worse outcome in patients with AGCTs. ${ }^{64,67-77}$ However, none of these parameters have been conclusively proven to reliably predict for disease recurrence. More recently, D'Angelo et al. reported that patients with FOXL2 mutated tumours had a worse disease-free and overall survival than those with the wild-type gene ${ }^{28}$ while Rosario et al. showed that women with homozygous FOXL2 mutations had significantly higher relapse rates. ${ }^{35}$ These findings remain to be further validated. Similarly, although granulosa theca cell tumours can also harbour the same FOXL2 mutation that characterises AGCT, there is currently no evidence to suggest that this should alter the classification or management of these neoplasms. ${ }^{37}$

Total hysterectomy with bilateral salpingo-oophorectomy is the standard therapy in peri- or post-menopausal women with AGCT. For those of child-bearing age, appropriate counselling and fertility-sparing surgical options may be considered in stage $1 \mathrm{~A}$ disease. In these instances, endometrial assessment should also be performed pre-operatively to exclude the possibility of co-existing endometrial hyperplasia and/or adenocarcinoma. ${ }^{78}$ The main challenge in the treatment of AGCTs lies in the management of recurrent or advanced stage disease. Currently, patients may be offered secondary cytoreductive surgery, chemotherapy or hormonal therapy (including aromatase inhibitors) and/or radiotherapy. ${ }^{79-82}$ However, these modalities often demonstrate only limited efficacy. The role of systemic therapy following 


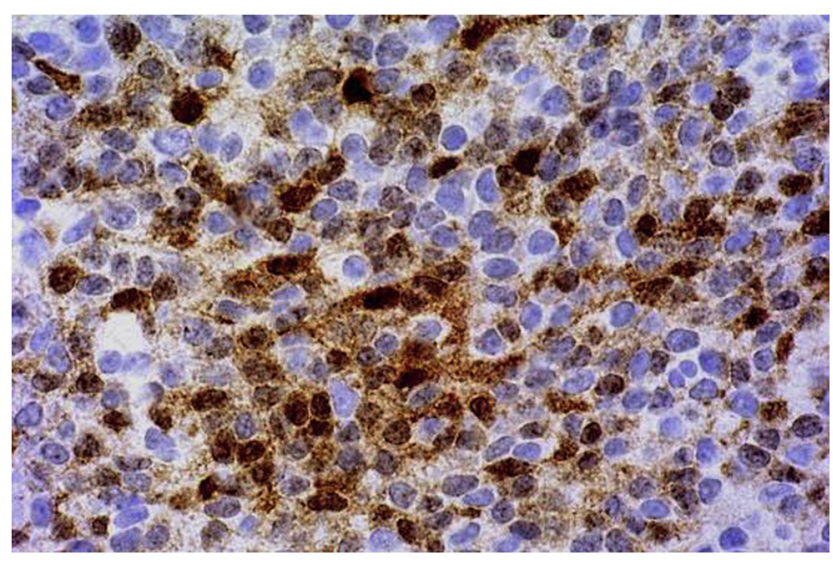

Fig. 3 Adult granulosa cell tumour demonstrating patchy nuclear and cytoplasmic calretinin positivity.

complete surgical debulking is also controversial. Close clinical up-follow or endocrine therapy has been adopted in some patients. ${ }^{83}$ The use of anti-angiogenic agents has also been explored, but the overall efficacy of these drugs remains to be assessed. ${ }^{84}$

\section{Juvenile granulosa cell tumour}

JGCTs account for 5-15\% of all granulosa cell tumours and occur most commonly within the first three decades of life. ${ }^{85}$ Prepubertal patients often present with isosexual pseudoprecocity secondary to hyperoestrogenism, ${ }^{86}$ although rarely, some may exhibit features of virilisation. ${ }^{87}$ Abdominal pain, distension and menstrual irregularities are common presentations in post-pubertal women. ${ }^{85}$

The vast majority of JGCTs present as unilateral tumours ranging in size from 3 to $>30 \mathrm{~cm}$. Most neoplasms have solid and cystic cut surfaces but some may be entirely solid or cystic. The solid areas show a tan-yellow or greyish appearance with foci of haemorrhage and/or necrosis while the cysts have serous or haemorrhagic contents. ${ }^{85}$ Microscopic examination reveals a nodular (Fig. 4A) or diffuse proliferation of cells embedded in an oedematous or myxoid stroma. The presence of follicle-like spaces of varying sizes and shapes, containing eosinophilic or basophilic secretions, is a characteristic feature. Cells show round, hyperchromatic nuclei and abundant eosinophilic or vacuolated cytoplasm (Fig. 4B). A variable degree of cytological atypia, including the presence of bizarre cells, may be encountered (Fig. 4C). Mitotic activity is also variable but generally brisk and atypical mitotic figures can be seen.

\section{Immunohistochemistry}

Tumour cells are positive for $\boldsymbol{\alpha}$-inhibin, ${ }^{52,88}$ calretinin, ${ }^{48,51}$ SF-1 and often express vimentin, ${ }^{88}$ WT- $1,{ }^{48}$ CD56, ${ }^{60}$ CD99, ${ }^{56}$ CD10, ${ }^{89}$ SMA, ${ }^{90}$ S100, cytokeratin ${ }^{88}$ and rarely, EMA. ${ }^{48}$ FOXL2 immunoexpression has also been identified in JGCTs (Fig. 4D).

\section{Genetic susceptibility}

Most JGCTs occur sporadically, but some can arise in association with Ollier's disease (enchondromatosis) $)^{85,91,92}$ and Maffucci's syndrome (enchondromatosis and soft tissue haemangiomas). ${ }^{93}$ Patients with Ollier's disease have an increased risk of developing central chondrosarcoma, gliomas and non-small cell lung carcinoma, ${ }^{94-96}$ while those with Maffucci's syndrome are predisposed to astrocytomas, pituitary adenomas and pancreatic adenocarcinomas. ${ }^{9,97}$

\section{Molecular profile}

Unlike AGCTs, the molecular basis of JGCTs has been less well characterised. In contrast to AGCTs, FOXL2 mutations rarely occur in JGCTs. Instead two activating mutations of the stimulatory alpha subunit of a trimeric $\mathrm{G}$ protein $(\mathrm{G} \alpha \mathrm{s})$, located at position 201, have been described in $30 \%$ of JGCT in one cohort. ${ }^{98}$ These R201C and R201H mutations may inhibit GTPase activity, maintaining $\mathrm{G} \alpha$ s in its active form, thus predisposing to cellular proliferation and tumour invasion. ${ }^{99,100}$ The same investigators also detected in-frame tandem duplications of exon 3 of $A K T 1$ as well as an array of $A K T 1$ point mutations resulting in the alteration of highly conserved residues, in a series of 16 JGCTs. ${ }^{101}$ Further analysis of the RNA-Seq data revealed a series of differentially expressed genes involved in cytokine and hormone signalling and cell division-related processes, suggesting that ATK1 activation may play a crucial role in the pathogenesis of JGCTs. ${ }^{101,102}$

Somatic DICERI mutations have also been identified in JGCTs. In one study, one of 14 JGCTs was found to harbour a somatic 'hotspot' DICER1 mutation, ${ }^{103}$ but none were identified in four JGCTs in another study. ${ }^{104}$

It has been suggested that the JGCTs occurring in patients with Ollier's disease and Maffucci's syndrome may have underlying somatic mosaic IDH1 and IDH2 mutations (predominantly involving Arg132 of IDH1 or Arg172 of IDH2), since these molecular aberrations have been described in both conditions. ${ }^{105}$ Interestingly, Kenny et al. reported an ovarian cellular fibroma occurring in a patient with Ollier's disease, which also harboured the IDH1 R123 mutation. ${ }^{106}$ The mutant $I D H$ gene produces 2 -hydroxyglutarate (2-HG) which induces histone hypermethylation. ${ }^{107}$ However, the exact role of either the mutant $I D H$ gene or $2-\mathrm{HG}$ in the pathogenesis of JGCT remains uncertain. ${ }^{\text {.08 }}$

\section{Management and outcome}

The prognosis of patients with JGCT is stage dependent. It has been suggested that the presence of gsp mutation may also have prognostic significance as patients with tumours harbouring this mutation often present with advanced stage disease or tumour recurrence. ${ }^{98}$ Similarly, another group of investigators also reported that patients with tumours demonstrating strong FOXL2 protein expression had worse overall and disease-free survival compared those with negative or weakly immunoreactive tumours, ${ }^{28}$ however this observation remains to be validated with further studies.

The survival rate for patients with stage I tumours is approximately $97 \%$, however those with advanced stage tumours usually succumb to the disease. ${ }^{85}$ The presence of cytological atypia or brisk mitotic activity does not affect prognosis in stage I tumours. ${ }^{88}$

Unilateral salpingo-oophorectomy with staging should be considered in young patients with unilateral disease wishing to preserve fertility, whereas total hysterectomy with bilateral salpingo-oophorectomy is the treatment of choice in patients with advanced stage disease. ${ }^{109}$ Adjuvant chemotherapy is also a consideration in this latter group as well as in patients 
with recurrent disease. ${ }^{109}$ In comparison to AGCTs, JGCTs are less likely to recur or metastasise and any tumour recurrences usually occur earlier (within 3 years of diagnosis). ${ }^{85}$

\section{SERTOLI-LEYDIG CELL TUMOURS}

SLCTs are rare neoplasms constituting $<0.5 \%$ of all ovarian tumours. They occur in patients of all age groups (mean 25 years) with well-differentiated tumours occurring in slightly older (mean 35 years) and retiform variants in younger women (mean 15 years). Patients may present with symptoms related to an ovarian mass, virilisation or less commonly, hyperoestrogrenic manifestations. The current WHO classification categorises SLCTs into well, moderate and poorly differentiated and retiform variants. Moderate and poorly differentiated as well as retiform variants may contain heterologous elements. $^{110}$

Most tumours are unilateral and can vary in size from microscopic to $>20 \mathrm{~cm}$, with larger size being a more common feature of poorly differentiated neoplasms. ${ }^{111}$ Gross examination shows solid, yellowish, lobulated cut surface although a cystic appearance can be appreciated in tumours with retiform or heterologous elements. ${ }^{112,113}$ The cysts in retiform neoplasms may contain oedematous or gelatinous, papillary or polypoid projections. Foci of necrosis and haemorrhage are common in poorly differentiated SLCTs.

On microscopic examination, well-differentiated SLCTs tend to be circumscribed and are composed of lobules of solid or hollow tubules, separated by fibromatous stroma. The tubules are lined by cuboidal to columnar Sertoli cells with basally placed nuclei, small nucleoli and abundant eosinophilic or pale vacuolated cytoplasm. Leydig cells are present within the stroma and some may also line tubules. The Leydig cells, which are seen singly or in groups, have variable intracytoplasmic lipid contents and some may also contain lipochrome pigment or Reinke crystals. ${ }^{114}$ Cytological atypia and mitotic activity are rare.

A lobular architecture is also seen in moderately differentiated SLCTs, with cellular areas separated by oedematous or less frequently fibromatous stroma. The cellular areas are composed of Sertoli cells arranged in nests, cords, solid or poorly formed tubules or diffuse sheets. Infrequently, cysts containing eosinophilic secretions as well as follicle-like spaces may be seen. The Sertoli cells appear immature with high nucleo-cytoplasmic ratio, small round to oval nuclei and inconspicuous nucleoli. Leydig cells may be present at the periphery of the lobules of Sertoli cells or more commonly, within the oedematous stroma (Fig. 5A).

Poorly differentiated SLCTs are characterised by a diffuse or spindle (sarcomatoid) proliferation of poorly differentiated Sertoli cells with hyperchromatic nuclei and scant cytoplasm, often associated with brisk mitotic activity (>10/10 HPFs). Leydig cells are typically inconspicuous. ${ }^{114}$ The histological appearance may be indistinguishable from that of a pure sarcoma, with more characteristic Sertoli cell elements and Leydig cells identified only after extensive sampling.

A retiform component is present in 15\% of SLCTs. ${ }^{114-116}$ Microscopically, this is characterised by a network of irregularly branching, narrow slit-like tubules and cysts with papillary or polypoid projections ${ }^{115}$ (Fig. 5B). The cysts and tubules may contain eosinophilic secretions and are lined by cuboidal cells with scant cytoplasm and round to oval nuclei, often exhibiting varying degrees of cytological atypia. Papillary and polypoid formations may be: (1) small and round or blunt with hyalinised cores (most common); (2) large and bulbous with oedematous cores; or (3) delicate and branching and lined by stratified cells reminiscent of the

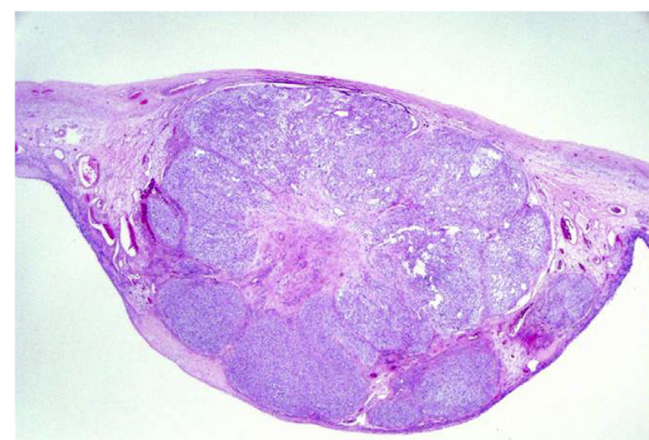

A
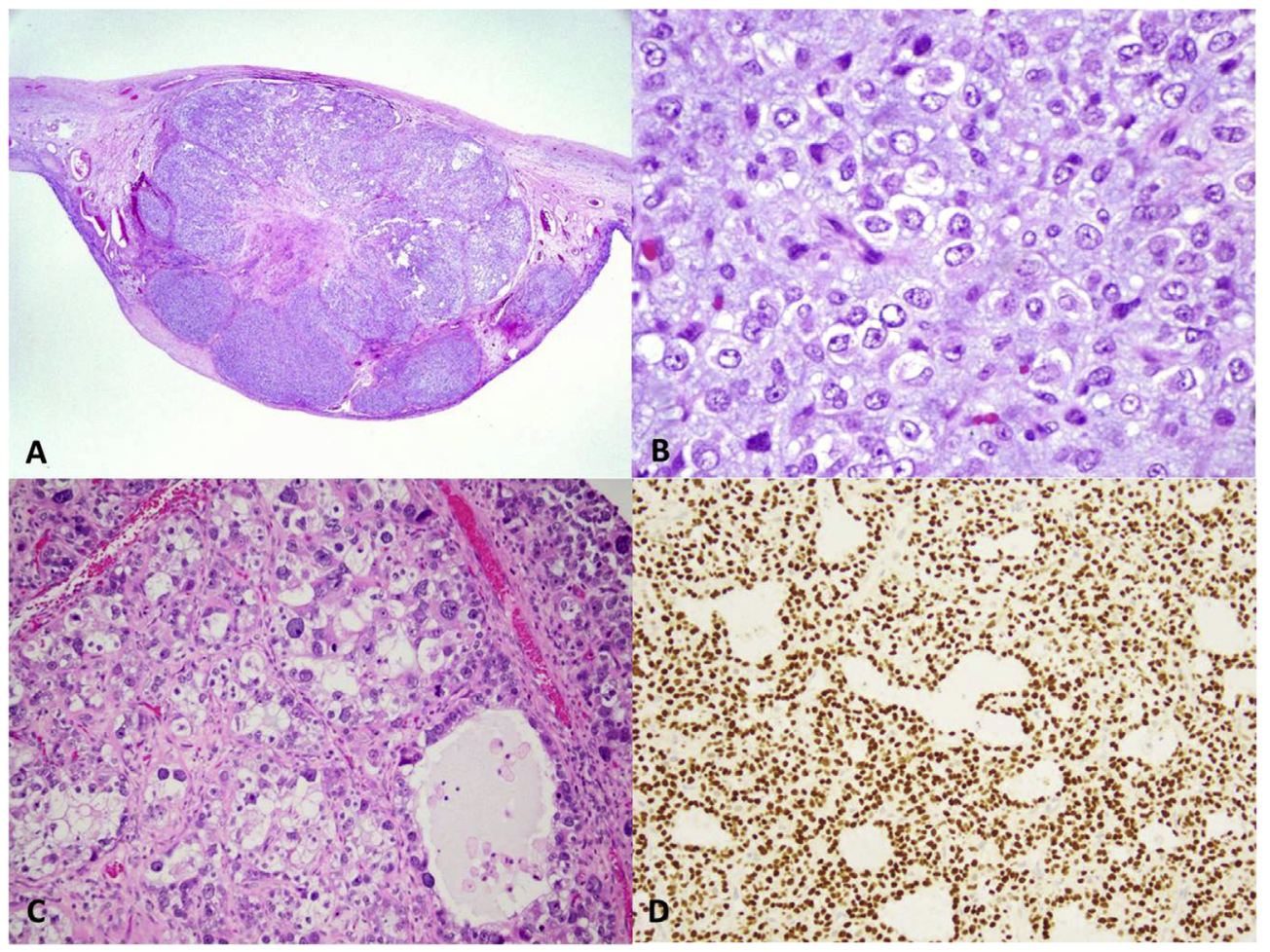

Fig. 4 Juvenile granulosa cell tumour. (A) Low magnification view showing a lobulated arrangement of tumour cells with intervening collagenous and oedematous stroma. (B) Granulosa cells with round, non-grooved nuclei and abundant vacuolated or eosinophilic cytoplasm are embedded in a myxoid stroma. (C) Tumour cells exhibiting marked cytological atypia. (D) Tumour cells showing FOXL2 nuclear expression. (Figure courtesy of Dr Robert Soslow.) 
papillary projections seen in serous borderline tumours. The surrounding stroma can be oedematous, hyalinised or densely cellular and immature. ${ }^{117}$

Heterologous elements are found in $20 \%$ of SLCTs, most frequently in moderately or poorly differentiated tumours and also in the retiform variants. ${ }^{111}$ The most common heterologous element is the intestinal-type mucinous epithe$\operatorname{lium}^{112,118}$ (Fig. 5C). This usually has a benign morphology although features of a borderline or malignant tumour have been described. ${ }^{113}$ Less commonly encountered heterologous elements include rhabdomyoblasts (Fig. 5D), ${ }^{11}$ cartilage, ${ }^{112}$ hepatoid elements, ${ }^{119}$ carcinoid tumour, ${ }^{112}$ or neuroblastoma. ${ }^{111}$

\section{Immunohistochemical profile}

SLCTs commonly express $\alpha$-inhibin, calretinin (more intense staining in Leydig cells), SF-1 and WT-1 $1^{39,53,54,120-122}$ and can also demonstrate immunoreactivity for CD99, ${ }^{48,53,56}$ Melan-A, ${ }^{123}$ CD56, CD10 ${ }^{89}$ and cytokeratin. ${ }^{48}$ FOXL2 is expressed in $-50 \%$ of SLCTs and immunoreactivity is confined to the Sertoli cells and in non-retiform variants. ${ }^{39}$ Poorly differentiated SLCTs may show minimal or no expression for markers of sex cord differentiation. EMA is also typically negative, except in heterologous epithelial elements. $^{48}$

\section{Molecular profile}

Somatic DICER1 mutations have been identified in $~ 60 \%$ of SLCTs. ${ }^{103,124-127}$ DICERI encodes for a RNA endoribonuclease that helps cleave precursor miRNA into mature miRNAs. ${ }^{128}$ MiRNAs are small (20-22 nucleotide) noncoding RNAs that regulate the translation of downstream target genes, with a crucial role in virtually all biological processes. Mutation in any component of the miRNA processing pathway can affect miRNAs expression, resulting in dysregulation of their target mRNA expression. MiRNAs are usually downregulated in cancer ${ }^{129}$ and have been shown to have oncogenic or tumour suppressive functions. The expression levels of DICER have widespread effects on the biogenesis of miRNA, and reduced expression has been associated with poor outcome in different cancer types. ${ }^{130-}$ ${ }^{134}$ Studies using mouse models have shown that loss of a single DICERI allele (haploinsufficiency) reduces the time to tumour formation ${ }^{135}$ and is also associated with poorer survival. ${ }^{136}$

DICER1 mutations in SLCTs are missense 'hotspots' mutations involving codons encoding metal-binding sites within the RNase IIIb catalytic centres, which are essential for microRNA interaction and cleavage. ${ }^{103}$ In one study, $38 \%$ of SLCTs were found to harbour the p.D1709N (c.5125G $>$ A) mutation in DICERI ${ }^{103}$ while another study reported the presence of p.E1705K (c.5113G $>$ A) in $80 \%$ of DICER1mutant tumours $^{124}$ (Fig. 6). There is no apparent association between DICER1 mutation status and the presence of heterologous or retiform differentiation. Interestingly, welldifferentiated SLCTs do not appear to be associated with DICER 1 mutations, however the number of tumours tested is limited and this finding remains to be validated with a larger cohort. $^{29,124}$

In addition to SLCTs, DICERl mutations have also been identified in SCT and other ovarian tumours such as JCGTs, unclassified SCSTs, gynandroblastoma, and rarely in yolk sac tumours, mixed germ cell tumours, dysgerminona/gonadoblastoma $^{29}$ and in cervical rhabdomyosarcoma ${ }^{124}$ as well as testicular germ cell tumours. ${ }^{103,104,137}$ No testicular Sertoli

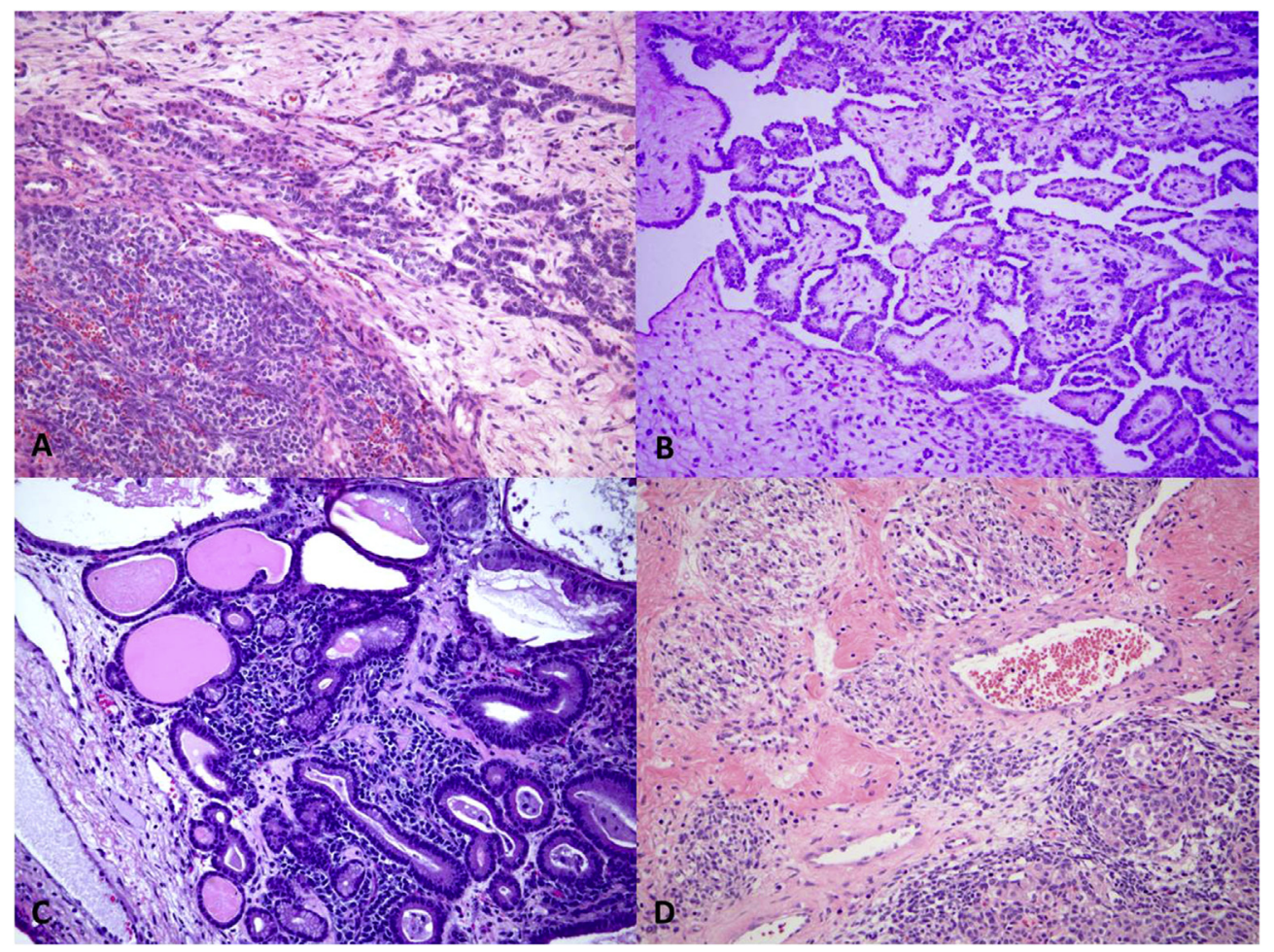

Fig. 5 Sertoli-Leydig cell tumour. (A) Tumour of intermediate differentiation with Sertoli cells arranged in nests, cords and poorly formed tubules and Leydig cells present at the periphery of the Sertoli cells lobules as well as within the oedematous stroma. (B) Retiform variant with papillary and focally retiform growth patterns. (C) Glands lined by gastrointestinal-type epithelium are present within a Sertoli-Leydig cell tumour of intermediate differentiation. (D) Tumour with heterologous (rhabdomyoblastic) elements (top left). 
DICER1 p.E1705K (c.5113G>A)

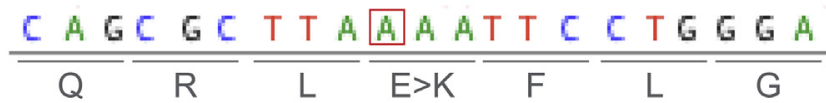

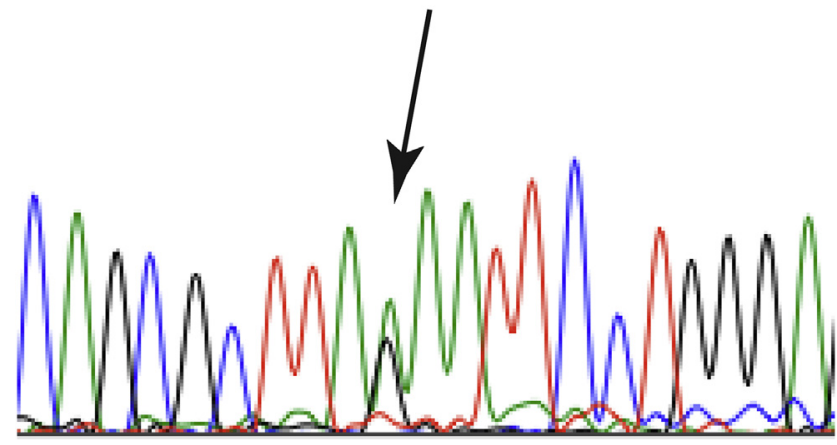

Fig. 6 Sertoli-Leydig cell tumour with the c.5113G>A DICER1 mutation, encoding an E1705K substitution (arrow). (Figure courtesy of Dr Britta Weigelt.)

cell tumours tested to date have been found to harbour this mutation. ${ }^{124}$ Table 3 summarises the results from various studies evaluating DICER1 mutation status in different ovarian and testicular tumour types.

No DICERI mutations have been identified in any AGCTs tested to date and no ovarian SCSTs have been found to harbour both FOXL2 and DICER1 mutations. ${ }^{103}$ Conlon et al. detected FOXL2 mutations in both the GCT-like and SLCT-like areas of the two DICERl wild-type gynandroblastomas and the authors noted that there were no apparent morphological differences between the DICERI-mutant and wild-type gynandroblastomas, or between DICERI-mutant and FOXL2-mutant gynandroblastomas. ${ }^{124}$ These findings further support the observation that DICER1 and FOXL2 mutations appear to be mutually exclusive in ovarian SCSTs.

Germline DICER1 mutations have also been reported. This was initially discovered in families with a predisposition for developing pleuropulmonary blastoma as well as other lesions such as cystic nephroma, multinodular goitre and ovarian SLCTs. ${ }^{138}$ It has since been shown that the DICER1 syndrome also confers an increased risk for other unusual tumours such as cervical embryonal rhabdomyosarcoma, ciliary-body medulloepithelioma, pituitary blastoma, cervical primitive neuroectodermal tumour, juvenile intestinal hamartomatous polyps and Wilms tumour. ${ }^{139-142}$ In contrast to somatic DICER1 mutations, germline defects are predominantly truncating mutations and are not restricted to 'hotspot' regions of the gene. Importantly, it has been shown that SLCTs with germline DICER1 mutations can also harbour somatic DICERI defects, ${ }^{103}$ therefore it has been suggested that referral for genetic testing should be considered in all patients with SLCTs.

SLCTs arising in patients with germline DICER 1 mutation tend to occur at a younger age (first and second decade) than those with sporadic tumours (mean 25 years). ${ }^{143}$ These tumours may exhibit heterogenous morphology with admixed juvenile granulosa cell tumour component or heterologous elements. ${ }^{127,143}$ A review of the SCSTs arising in three patients with germline DICER1 mutation showed tumours with mixed cytomorphology including sertoliform, JGCT-like,
Table 3 DICERl mutation in ovarian and non-ovarian tumours

\begin{tabular}{|c|c|}
\hline Reference & Tumours with DICER1 mutation \\
\hline \multirow[t]{8}{*}{ Heravi-Moussavi et al., $2012^{103}$} & $26 / 43(60 \%)$ SLCTs \\
\hline & 1/14 (7\%) JGCTs \\
\hline & $0 / 15(0 \%)$ AGCTs \\
\hline & $2 / 15(13 \%)$ Yolk sac tumours \\
\hline & $0 / 1(0 \%)$ Dysgerminoma \\
\hline & $0 / 1(0 \%)$ Mixed germ cell tumour \\
\hline & $0 / 5(0 \%)$ Immature teratomas \\
\hline & $1 / 8(12 \%)$ Mature teratomas \\
\hline \multirow{19}{*}{$\begin{array}{l}\text { De Boer } \text { et al., } 2012^{137} \\
\text { Witkowski et al., } 2013^{104}\end{array}$} & $1 / 96(1 \%)$ Testicular germ cell tumours \\
\hline & $8 / 15(53 \%)$ SLCTs \\
\hline & $0 / 4(0 \%)$ JGCTs \\
\hline & 1/7 (14\%) Unclassified SCSTs \\
\hline & $0 / 1(0 \%)$ Leydig cell tumour \\
\hline & $0 / 1(0 \%)$ SCTAT \\
\hline & $\begin{array}{l}\text { 0/20 }(0 \%) \text { Ovarian mature/immature } \\
\text { teratomas }\end{array}$ \\
\hline & $0 / 20(0 \%)$ Ovarian yolk sac tumours \\
\hline & $\begin{array}{l}\text { 0/1 }(0 \%) \text { Ovarian embryonal } \\
\text { carcinoma }\end{array}$ \\
\hline & $\begin{array}{l}\text { 2/14 (17\%) Ovarian mixed malignant } \\
\text { germ cell tumours }\end{array}$ \\
\hline & $\begin{array}{l}1 / 5(20 \%) \text { Dyserminoma/ } \\
\text { gonadoblastomas }\end{array}$ \\
\hline & 0/39 (0\%) Dysgerminomas \\
\hline & $\begin{array}{l}\text { 0/1 }(0 \%) \text { Embryonal } \\
\text { rhabdomyosarcoma }\end{array}$ \\
\hline & 0/7 (0\%) SCCOHTs \\
\hline & $\begin{array}{l}0 / 3(0 \%) \text { Testicular mature/immature } \\
\text { teratomas }\end{array}$ \\
\hline & $1 / 7(14 \%)$ Testicular yolk sac tumours \\
\hline & $\begin{array}{l}0 / 1(0 \%) \text { Testicular embryonal } \\
\text { carcinoma }\end{array}$ \\
\hline & $\begin{array}{l}1 / 5(20 \%) \text { Testicular mixed malignant } \\
\text { germ cell tumours }\end{array}$ \\
\hline & $0 / 3(0 \%)$ Seminomas \\
\hline \multirow[t]{8}{*}{ Conlon et al., $2015^{124}$} & $20 / 32(63 \%)$ SLCTs \\
\hline & 2/5 (40\%) Gynandroblastomas \\
\hline & $5 / 8(63 \%)$ Sertoli cell tumours \\
\hline & $0 / 1(0 \%)$ SCTAT \\
\hline & 0/1 (0\%) Unclassified SCST \\
\hline & $\begin{array}{l}1 / 4(25 \%) \text { Embryonal } \\
\text { rhabdomyosarcomas }\end{array}$ \\
\hline & $\begin{array}{l}\text { 1/4 }(25 \%) \text { Carcinosarcomas with } \\
\text { rhabdomyosarcomatous } \\
\text { differnentiation }\end{array}$ \\
\hline & 0/15 (0\%) Testicular SCSTs \\
\hline \multirow[t]{9}{*}{ Goulvent et al., $2016^{29}$} & $6 / 19(32 \%)$ SLCTs \\
\hline & $2 / 8(25 \%)$ JGCTs \\
\hline & $1 / 12(8 \%)$ Unidifferentiated SCSTs \\
\hline & $0 / 101(0 \%)$ AGCTs \\
\hline & 0/10 (0\%) Fibrothecomas \\
\hline & $0 / 2(0 \%)$ Sertoli cell tumours \\
\hline & $0 / 2(0 \%)$ Steroid cell tumours \\
\hline & $0 / 1(0 \%)$ SST \\
\hline & $0 / 1(0 \%)$ SCTAT \\
\hline Kato et al., $2017^{125}$ & $6 / 10(60 \%)$ SLCTs \\
\hline
\end{tabular}

AGCT, adult granulosa cell tumour; JGCT, juvenile granulosa cell tumour SCCOHT, small cell carcinoma of hypercalcemic type; SCST, sex cord stromal tumour; SCTAT, sex cord tumour with annular tubules; SST, sclerosing stromal tumour.

and unclassifiable elements, suggesting that the morphological spectrum of SCSTs arising in this setting can be diverse and may not just be restricted to SLCTs. ${ }^{127}$

\section{Management and outcome}

The majority of SLCTs are benign with malignant behaviour observed in $<15 \%$ of patients. Important prognostic factors include stage, degree of differentiation, ${ }^{113,144}$ tumour 
rupture $^{113,114}$ and the presence of retiform component ${ }^{117}$ or heterologous elements. ${ }^{11,113,144}$ Poorly differentiated tumours as well as those with retiform or heterologous elements are generally associated with more aggressive behaviour. ${ }^{114}$

Most ( $80 \%)$ patients present with stage 1a disease and can be managed by fertility-sparing surgery, following complete surgical staging, without the need for further adjuvant therapy. ${ }^{114,144}$ More aggressive surgery and chemotherapy are indicated in advanced stage tumours. Adjuvant therapy should also be considered in stage I tumours that are poorly differentiated or contain mesenchymal heterologous elements and for neoplasms of intermediate differentiation that have ruptured. ${ }^{145,146}$ In contrast to AGCTs which are characteristically associated with late disease recurrence, SLCTs generally recur earlier and recurrences are often confined to the pelvis and abdomen. ${ }^{113}$

\section{CONCLUSIONS}

SCSTs often present as a diagnostic challenge as they encompass a heterogenous group of tumours with varied and occasionally overlapping morphology. Most pathologists have limited experience with these neoplasms as many of them are uncommon in the routine diagnostic setting. The use of a panel of immunohistochemical markers which are sensitive and specific for sex-cord stromal differentiation, including FOXL2, can help to distinguish these tumours from some morphological mimics, but this is of limited value in differentiating between different subtypes of SCSTs. In instances where a confident diagnosis of an AGCT cannot be rendered based on morphological or immunohistochemical features, FOXL2 mutation analysis should be considered, given the specificity of this mutation for AGCTs. A correct diagnosis of AGCT is important as patients with these tumours have a propensity for late disease recurrences and metastases and require long term follow-up. Similarly, DICERl mutation is also relatively specific for SLCTs although it is present in a smaller proportion of tumours. The identification of a SLCT, particularly in a young patient, should prompt the pathologist to consider the possibility of an underlying DICER1 syndrome and refer the patient for further genetic work-up. A better understanding of the molecular pathogenesis underlying SCSTs can help improve tumour classification and disease prognostication and also potentially lead to the discovery of more effective treatment strategies which are currently lacking in this group of tumours.

Conflicts of interest and sources of funding: The authors state that there are no conflicts of interest to disclose.

Address for correspondence: Diana Lim, Department of Pathology, National University Hospital, 5 Lower Kent Ridge Road, 119074 Singapore. E-mail: diana_gz_lim@nuhs.edu.sg

\section{References}

1. Scully RE, Young RH, Clement PB. Tumors of the Ovary, Maldeveloped Gonads, Fallopian Tube, and Broad Ligament. Atlas of Tumor Pathology. Third series, Fascicle 23. Washington, DC: Armed Forces Institute of Pathology, 1999; Chapters 9-11.

2. Kurman RJ, Carcangiu ML, Herrington CS, et al. WHO Classification of Tumours of the Female Reproductive Organs. 4th ed. Lyon: IARC Press, 2014; 44-56.
3. Pectasides D, Pectasides E, Psyrri A. Granulosa cell tumor of the ovary. Cancer Treat Rev 2008; 34: 1-12.

4. Stuart GC, Dawson LM. Update on granulosa cell tumours of the ovary. Curr Opin Obstet Gynecol 2003; 15: 33-7.

5. Fox H, Agrawal K, Langley FA. A clinicopathologic study of 92 cases of granulosa cell tumor of the ovary with special reference to the factors influencing prognosis. Cancer 1975; 35: 231-41.

6. Nakashima N, Young RH, Scully RE. Androgenic granulosa cell tumors of the ovary. A clinicopathologic analysis of 17 cases and review of the literature. Arch Pathol Lab Med 1984; 108: 786-91.

7. Ganesan R, Hirschowitz L, Baltrusaityte I, et al. Luteinized adult granulosa cell tumor-a series of 9 cases: revisiting a rare variant of adult granulosa cell tumor. Int J Gynecol Pathol 2011; 30: 452-9.

8. Young RH, Oliva E, Scully RE. Luteinized adult granulosa cell tumors of the ovary: a report of four cases. Int J Gynecol Pathol 1994; 13: $302-10$.

9. Young RH, Scully RE. Ovarian sex cord-stromal tumors with bizarre nuclei: a clinicopathologic analysis of 17 cases. Int J Gynecol Pathol 1983; $1: 325-35$.

10. Susil BJ, Sumithran E. Sarcomatous change in granulosa cell tumor. Hum Pathol 1987; 18: 397-9.

11. Nogales FF, Concha A, Plata C, et al. Granulosa cell tumor of the ovary with diffuse true hepatic differentiation simulating stromal luteinization. Am J Surg Pathol 1993; 17: 85-90.

12. Mayr D, Kaltz-Wittmer C, Arbogast S, et al. Characteristic pattern of genetic aberrations in ovarian granulosa cell tumors. Mod Pathol 2002; 15: $951-7$.

13. Lin YS, Eng HL, Jan YJ, et al. Molecular cytogenetics of ovarian granulosa cell tumors by comparative genomic hybridization. Gynecol Oncol 2005; 97: 68-73.

14. Caburet S, Anttonen M, Todeschini AL, et al. Combined comparative genomic hybridization and transcriptomic analyses of ovarian granulosa cell tumors point to novel candidate driver genes. BMC Cancer 2015; 15: 251.

15. Shah SP, Kobel M, Senz J, et al. Mutation of FOXL2 in granulosa-cell tumors of the ovary. N Engl J Med 2009; 360: 2719-29.

16. Cocquet J, Pailhoux E, Jaubert F, et al. Evolution and expression of FOXL2. J Med Genet 2002; 39: 916-21.

17. Schmidt D, Ovitt CE, Anlag K, et al. The murine winged-helix transcription factor Fox12 is required for granulosa cell differentiation and ovary maintenance. Development 2004; 131: 933-42.

18. Moumne L, Batista F, Benayoun BA, et al. The mutations and potential targets of the forkhead transcription factor FOXL2. Mol Cell Endocrinol 2008; 282: 2-11.

19. Tuteja G, Kaestner KH. Forkhead transcription factors II. Cell 2007; 131: 192 .

20. Ellsworth BS, Burns AT, Escudero KW, et al. The gonadotropin releasing hormone $(\mathrm{GnRH})$ receptor activating sequence (GRAS) is a composite regulatory element that interacts with multiple classes of transcription factors including Smads, AP-1 and a forkhead DNA binding protein. Mol Cell Endocrinol 2003; 206: 93-111.

21. Park M, Shin E, Won M, et al. FOXL2 interacts with steroidogenic factor-1 (SF-1) and represses SF-1-induced CYP17 transcription in granulosa cells. Mol Endocrinol 2010; 24: 1024-36.

22. Crisponi L, Deiana M, Loi A, et al. The putative forkhead transcription factor FOXL2 is mutated in blepharophimosis/ptosis/epicanthus inversus syndrome. Nat Genet 2001; 27: 159-66.

23. Benayoun BA, Georges AB, L'Hote D, et al. Transcription factor FOXL2 protects granulosa cells from stress and delays cell cycle: role of its regulation by the SIRT1 deacetylase. Hum Mol Genet 2011; 20: $1673-86$.

24. Kim JH, Yoon S, Park M, et al. Differential apoptotic activities of wildtype FOXL2 and the adult-type granulosa cell tumor-associated mutant FOXL2 (C134W). Oncogene 2011; 30: 1653-63.

25. Leung DT, Fuller PJ, Chu S. Impact of FOXL2 mutations on signaling in ovarian granulosa cell tumors. Int J Biochem Cell Biol 2016; 72: $51-4$.

26. Benayoun BA, Anttonen M, L'Hote D, et al. Adult ovarian granulosa cell tumor transcriptomics: prevalence of FOXL2 target genes misregulation gives insights into the pathogenic mechanism of the p.Cys134Trp somatic mutation. Oncogene 2013; 32: 2739-46.

27. Kim MS, Hur SY, Yoo NJ, et al. Mutational analysis of FOXL 2 codon 134 in granulosa cell tumour of ovary and other human cancers. J Pathol 2010; 221: 147-52.

28. D'Angelo E, Mozos A, Nakayama D, et al. Prognostic significance of FOXL2 mutation and mRNA expression in adult and juvenile granulosa cell tumors of the ovary. Mod Pathol 2011; 24: 1360-7.

29. Goulvent T, Ray-Coquard I, Borel S, et al. DICER1 and FOXL2 mutations in ovarian sex cord-stromal tumours: a GINECO Group study. Histopathology 2016; 68: 279-85. 
30. Jamieson S, Butzow R, Andersson N, et al. The FOXL2 C134W mutation is characteristic of adult granulosa cell tumors of the ovary. Mod Pathol 2010; 23: 1477-85.

31. Kim T, Sung CO, Song SY, et al. FOXL2 mutation in granulosa-cell tumours of the ovary. Histopathology 2010; 56: 408-10.

32. Kommoss S, Gilks CB, Penzel R, et al. A current perspective on the pathological assessment of FOXL2 in adult-type granulosa cell tumours of the ovary. Histopathology 2014; 64: 380-8.

33. Oparka R, Cassidy A, Reilly S, et al. The C134W (402 C>G) FOXL2 mutation is absent in ovarian gynandroblastoma: insights into the genesis of an unusual tumour. Histopathology 2012; 60: 838-42.

34. Oseto K, Suzumori N, Nishikawa R, et al. Mutational analysis of FOXL2 p.C134W and expression of bone morphogenetic protein 2 in Japanese patients with granulosa cell tumor of ovary. J Obstet Gynaecol Res 2014; 40: 1197-204.

35. Rosario R, Wilson M, Cheng WT, et al. Adult granulosa cell tumours (GCT): clinicopathological outcomes including FOXL2 mutational status and expression. Gynecol Oncol 2013; 131: 325-9.

36. Zannoni GF, Improta G, Petrillo M, et al. FOXL2 molecular status in adult granulosa cell tumors of the ovary: a study of primary and metastatic cases. Oncol Lett 2016; 12: 1159-63.

37. Nolan A, Joseph NM, Sangoi AR, et al. FOXL2 mutation status in granulosa theca cell tumors of the ovary. Int J Gynecol Pathol 2017; 36: $568-74$.

38. Lima JF, Jin L, de Araujo AR, et al. FOXL2 mutations in granulosa cell tumors occurring in males. Arch Pathol Lab Med 2012; 136 $825-8$.

39. Al-Agha OM, Huwait HF, Chow C, et al. FOXL2 is a sensitive and specific marker for sex cord-stromal tumors of the ovary. Am J Surg Pathol 2011; 35: 484-94.

40. Buza N, Wong S, Hui P. FOXL2 mutation analysis of ovarian sex cordstromal tumors: genotype-phenotype correlation with diagnostic considerations. Int J Gynecol Pathol 2017; Jul 11: (Epub ahead of print).

41. Irving $\mathrm{JA}$, Lee $\mathrm{CH}$, Yip $\mathrm{S}$, et al. Microcystic stromal tumor: distinctive ovarian sex cord-stromal neoplasm characterized by FOXL2, SF-1, WT-1, Cyclin D1, and beta-catenin nuclear expression and CTNNB1 mutations. Am J Surg Pathol 2015; 39: 1420-6.

42. McCluggage WG, Singh N, Kommoss S, et al. Ovarian cellular fibromas lack FOXL2 mutations: a useful diagnostic adjunct in the distinction from diffuse adult granulosa cell tumor. Am J Surg Pathol 2013; 37: 1450-5.

43. Meurgey A, Descotes F, Mery-Lamarche E, et al. Lack of mutation of DICER1 and FOXL2 genes in microcystic stromal tumor of the ovary. Virchows Arch 2017; 470: 225-9.

44. Schrader KA, Gorbatcheva B, Senz J, et al. The specificity of the FOXL2 c. $402 \mathrm{C}>\mathrm{G}$ somatic mutation: a survey of solid tumors. PLoS One 2009; 4, e7988.

45. Kommoss S, Anglesio MS, Mackenzie R, et al. FOXL2 molecular testing in ovarian neoplasms: diagnostic approach and procedural guidelines. Mod Pathol 2013; 26: 860-7.

46. Farkkila A, McConechy MK, Yang W, et al. FOXL2 402C $>$ G mutation can be identified in the circulating tumor DNA of patients with adult-type granulosa cell tumor. J Mol Diagn 2017; 19: 126-36.

47. Bai S, Wei S, Ziober A, et al. SALL4 and SF-1 are sensitive an specific markers for distinguishing granulosa cell tumors from yolk sac tumors. Int J Surg Pathol 2013; 21: 121-5.

48. Deavers MT, Malpica A, Liu J, et al. Ovarian sex cord-stromal tumors: an immunohistochemical study including a comparison of calretinin and inhibin. Mod Pathol 2003; 16: 584-90.

49. Kommoss F, Oliva E, Bhan AK, et al. Inhibin expression in ovarian tumors and tumor-like lesions: an immunohistochemical study. Mod Pathol 1998; 11: 656-64.

50. McCluggage WG, Maxwell P. Immunohistochemical staining for calretinin is useful in the diagnosis of ovarian sex cord-stromal tumours. Histopathology 2001; 38: 403-8.

51. Movahedi-Lankarani S, Kurman RJ. Calretinin, a more sensitive but less specific marker than alpha-inhibin for ovarian sex cord-stromal neoplasms: an immunohistochemical study of 215 cases. Am J Surg Pathol 2002: 26: 1477-83.

52. Rishi M, Howard LN, Bratthauer GL, et al. Use of monoclonal antibody against human inhibin as a marker for sex cord-stromal tumors of the ovary. Am J Surg Pathol 1997; 21: 583-9.

53. Zhao C, Vinh TN, McManus K, et al. Identification of the most sensitive and robust immunohistochemical markers in different categories of ovarian sex cord-stromal tumors. Am J Surg Pathol 2009; 33 354-66.

54. Zhao C, Barner R, Vinh TN, et al. SF-1 is a diagnostically useful immunohistochemical marker and comparable to other sex cordstromal tumor markers for the differential diagnosis of ovarian sertoli cell tumor. Int J Gynecol Pathol 2008; 27: 507-14.
55. Cathro HP, Stoler MH. The utility of calretinin, inhibin, and WT1 immunohistochemical staining in the differential diagnosis of ovarian tumors. Hum Pathol 2005; 36: 195-201.

56. Matias-Guiu X, Pons C, Prat J. Mullerian inhibiting substance, alphainhibin, and CD99 expression in sex cord-stromal tumors and endometrioid ovarian carcinomas resembling sex cord-stromal tumors. Hum Pathol 1998; 29: 840-5.

57. Costa MJ, DeRose PB, Roth LM, et al. Immunohistochemical phenotype of ovarian granulosa cell tumors: absence of epithelia membrane antigen has diagnostic value. Hum Pathol 1994; 25: 60-6.

58. Farinola MA, Gown AM, Judson K, et al. Estrogen receptor alpha and progesterone receptor expression in ovarian adult granulosa cell tumors and Sertoli-Leydig cell tumors. Int J Gynecol Pathol 2007; 26: $375-82$.

59. Guerrieri C, Franlund B, Malmstrom H, et al. Ovarian endometrioid carcinomas simulating sex cord-stromal tumors: a study using inhibin and cytokeratin 7. Int J Gynecol Pathol 1998; 17: 266-71.

60. Ohishi Y, Kaku T, Oya M, et al. CD56 expression in ovarian granulosa cell tumors, and its diagnostic utility and pitfalls. Gynecol Oncol 2007; 107: $30-8$.

61. Riopel MA, Perlman EJ, Seidman JD, et al. Inhibin and epithelial membrane antigen immunohistochemistry assist in the diagnosis of sex cord-stromal tumors and provide clues to the histogenesis of hypercalcemic small cell carcinomas. Int J Gynecol Pathol 1998; 17: 46-53.

62. Ahmed E, Young RH, Scully RE. Adult granulosa cell tumor of the ovary with foci of hepatic cell differentiation: a report of four cases and comparison with two cases of granulosa cell tumor with Leydig cells. Am J Surg Pathol 1999; 23: 1089-93.

63. Lee YK, Park NH, Kim JW, et al. Characteristics of recurrence in adult-type granulosa cell tumor. Int J Gynecol Cancer 2008; 18: $642-7$

64. Bryk S, Farkkila A, Butzow R, et al. Clinical characteristics and survival of patients with an adult-type ovarian granulosa cell tumor: a 56year single-center experience. Int J Gynecol Cancer 2015; 25: 33-41.

65. Karalok A, Turan T, Ureyen I, et al. Prognostic factors in adult granulosa cell tumor: a long follow-up at a single center. Int J Gynecol Cancer 2016; 26: 619-25.

66. Bjorkholm E, Silfversward C. Prognostic factors in granulosa-cell tumors. Gynecol Oncol 1981; 11: 261-74.

67. Fox H. Pathologic prognostic factors in early stage adult-type granulosa cell tumors of the ovary. Int J Gynecol Cancer 2003; 13: 1-4.

68. Bryk S, Farkkila A, Butzow R, et al. Characteristics and outcome of recurrence in molecularly defined adult-type ovarian granulosa cell tumors. Gynecol Oncol 2016; 143: 571-7.

69. Ertas IE, Gungorduk K, Taskin S, et al. Prognostic predictors and spread patterns in adult ovarian granulosa cell tumors: a multicenter long-term follow-up study of 108 patients. Int J Clin Oncol 2014; 19: 912-20.

70. Farkkila A, Andersson N, Butzow R, et al. HER2 and GATA4 are new prognostic factors for early-stage ovarian granulosa cell tumor-a longterm follow-up study. Cancer Med 2014; 3: 526-36.

71. Mangili G, Ottolina J, Gadducci A, et al. Long-term follow-up is crucial after treatment for granulosa cell tumours of the ovary. $\mathrm{Br} J$ Cancer 2013; 109: 29-34.

72. Shim SH, Lee SJ, Kim DY, et al. A Long-term follow-up study of 91 cases with ovarian granulosa cell tumors. Anticancer Res 2014; 34: $1001-10$.

73. Stewart CJ, Doherty D, Guppy R, et al. beta-Catenin and E-cadherin expression in stage I adult-type granulosa cell tumour of the ovary: correlation with tumour morphology and clinical outcome. Histopathology 2013; 62: 257-66.

74. Suri A, Carter EB, Horowitz N, et al. Factors associated with an increased risk of recurrence in women with ovarian granulosa cell tumors. Gynecol Oncol 2013; 131: 321-4.

75. Ud Din N, Kayani N. Recurrence of adult granulosa cell tumor of the ovary: experience at a tertiary care center. Ann Diagn Pathol 2014; 18 $125-8$.

76. van Meurs HS, Schuit E, Horlings HM, et al. Development and internal validation of a prognostic model to predict recurrence free survival in patients with adult granulosa cell tumors of the ovary. Gynecol Oncol 2014; 134: 498-504.

77. Wilson MK, Fong P, Mesnage S, et al. Stage I granulosa cell tumours: a management conundrum? Results of long-term follow up. Gynecol Oncol 2015; 138: 285-91.

78. Evans 3rd AT, Gaffey TA, Malkasian Jr GD, et al. Clinicopathologic review of 118 granulosa and 82 theca cell tumors. Obstet Gynecol 1980; 55: 231-8.

79. E C, Samant R, Fung MF, et al. Palliative radiotherapy for recurrent granulosa cell tumor of the ovary: a report of 3 cases with radiologica evidence of response. Gynecol Oncol 2006; 102: 406-10. 
80. Korach J, Perri T, Beiner M, et al. Promising effect of aromatase inhibitors on recurrent granulosa cell tumors. Int J Gynecol Cancer 2009 19: $830-3$.

81. Pautier P, Gutierrez-Bonnaire M, Rey A, et al. Combination of bleomycin, etoposide, and cisplatin for the treatment of advanced ovarian granulosa cell tumors. Int J Gynecol Cancer 2008; 18: 446-52.

82. Savage P, Constenla D, Fisher C, et al. Granulosa cell tumours of the ovary: demographics, survival and the management of advanced disease. Clin Oncol 1998; 10: 242-5.

83. van Meurs HS, van Lonkhuijzen LR, Limpens J, et al. Hormone therapy in ovarian granulosa cell tumors: a systematic review. Gynecol Oncol 2014; 134: 196-205.

84. Brown J, Brady WE, Schink J, et al. Efficacy and safety of bevacizumab in recurrent sex cord-stromal ovarian tumors: results of a phase 2 trial of the Gynecologic Oncology Group. Cancer 2014; 120: $344-51$.

85. Young RH, Dickersin GR, Scully RE. Juvenile granulosa cell tumor of the ovary. A clinicopathological analysis of 125 cases. Am J Surg Pathol 1984; 8: 575-96.

86. Zaloudek C, Norris HJ. Granulosa tumors of the ovary in children: a clinical and pathologic study of 32 cases. Am J Surg Pathol 1982; 6: 503-12.

87. Vassal G, Flamant F, Caillaud JM, et al. Juvenile granulosa cell tumor of the ovary in children: a clinical study of 15 cases. J Clin Oncol 1988 ; 6: $990-5$.

88. Kondi-Pafiti A, Grapsa D, Kairi-Vassilatou E, et al. Granulosa cell tumors of the ovary: a clinicopathologic and immunohistochemical study of 21 cases. Eur J Gynaecol Oncol 2010; 31: 94-8.

89. Oliva E, Garcia-Miralles N, Vu Q, et al. CD10 expression in pure stromal and sex cord-stromal tumors of the ovary: an immunohistochemical analysis of 101 cases. Int J Gynecol Pathol 2007; 26: 359-67.

90. Perez-Atayde AR, Joste N, Mulhern H. Juvenile granulosa cell tumor of the infantile testis. Evidence of a dual epithelial-smooth muscle differentiation. Am J Surg Pathol 1996; 20: 72-9.

91. Leyva-Carmona M, Vazquez-Lopez MA, Lendinez-Molinos F. Ovarian juvenile granulosa cell tumors in infants. J Pediatr Hemato Oncol 2009; 31: 304-6.

92. Vaz RM, Turner C. Ollier disease (enchondromatosis) associated with ovarian juvenile granulosa cell tumor and precocious pseudopuberty. I Pediatr 1986; 108: 945-7.

93. Tanaka Y, Sasaki Y, Nishihira H, et al. Ovarian juvenile granulosa cell tumor associated with Maffucci's syndrome. Am J Clin Pathol 1992; 97: $523-7$

94. Hofman S, Heeg M, Klein JP, et al. Simultaneous occurrence of a supra- and an infratentorial glioma in a patient with Ollier's disease: more evidence for non-mesodermal tumor predisposition in multiple enchondromatosis. Skeletal Radiol 1998; 27: 688-91.

95. Schwartz HS, Zimmerman NB, Simon MA, et al. The malignan potential of enchondromatosis. J Bone Jt Surg Am 1987; 69: $269-74$.

96. Sendur OF, Turan Y, Odabasi BB, et al. A case of Ollier disease with non-small cell lung cancer and review of the literature. Rheumatol In 2010; 30: 699-703.

97. Ranger A, Szymczak A. Do intracranial neoplasms differ in Ollier disease and Maffucci syndrome? An in-depth analysis of the literature. Neurosurgery 2009; 65: 1106-13.

98. Kalfa N, Ecochard A, Patte C et al. Activating mutations of the stimulatory g protein in juvenile ovarian granulosa cell tumors: a new prognostic factor? J Clin Endocrinol Metab 2006; 91: 1842-7.

99. Chien J, Wong E, Nikes E, et al. Constitutive activation of stimulatory guanine nucleotide binding protein $(\mathrm{G}(\mathrm{S})$ alphaQL)-mediated signaling increases invasiveness and tumorigenicity of PC-3M prostate cancer cells. Oncogene 1999; 18: 3376-82.

100. Regnauld K, Nguyen QD, Vakaet L, et al. G-protein alpha(olf) subuni promotes cellular invasion, survival, and neuroendocrine differentiation in digestive and urogenital epithelial cells. Oncogene 2002; 21 4020-31.

101. Bessiere L, Todeschini AL, Auguste A, et al. A hot-spot of in-frame duplications activates the oncoprotein AKT1 in juvenile granulosa cell tumors. EBioMedicine 2015; 2: 421-31.

102. Auguste A, Bessiere L, Todeschini AL, et al. Molecular analyses of juvenile granulosa cell tumors bearing AKT1 mutations provide insights into tumor biology and therapeutic leads. Hum Mol Genet 2015 24: 6687-98.

103. Heravi-Moussavi A, Anglesio MS, Cheng SW, et al. Recurrent somatic DICER1 mutations in nonepithelial ovarian cancers. $N$ Engl $J$ Med 2012; 366: 234-42.

104. Witkowski L, Mattina J, Schonberger S, et al. DICER1 hotspot mutations in non-epithelial gonadal tumours. Br J Cancer 2013; 109: $2744-50$.
105. Amary MF, Damato S, Halai D, et al. Ollier disease and Maffucc syndrome are caused by somatic mosaic mutations of IDH1 and IDH2. Nat Genet 2011; 43: 1262-5.

106. Kenny SL, Patel K, Humphries A, et al. Ovarian cellular fibroma harbouring an isocitrate dehydrogenase 1 (1DH1) mutation in a patien with Ollier disease: evidence for a causal relationship. Histopathology 2013; 62: 667-70

107. Jin Y, Elalaf H, Watanabe M, et al. Mutant IDH1 dysregulates the differentiation of mesenchymal stem cells in association with genespecific histone modifications to cartilage- and bone-related genes. PLoS One 2015; 10: e0131998.

108. Verdegaal SH, Bovee JV, Pansuriya TC, et al. Incidence, predictive factors, and prognosis of chondrosarcoma in patients with Ollier disease and Maffucci syndrome: an international multicenter study of 161 patients. Oncologist 2011; 16: 1771-9.

109. Erdreich-Epstein A, Monforte HL, Lavey RS, et al. Successful multimodality therapy of recurrent multifocal juvenile granulosa cell tumor of the ovary. J Pediatr Hematol Oncol 2002; 24: 229-33.

110. Kurman RJ, Carcangiu ML, Herrington CS, et al. WHO Classification of Tumours of the Female Reproductive Organs. 4th ed. Lyon: IARC Press, 2014; 54-6.

111. Prat J, Young RH, Scully RE. Ovarian Sertoli-Leydig cell tumors with heterologous elements. II. Cartilage and skeletal muscle: a clinicopathologic analysis of twelve cases. Cancer 1982; 50: 2465-75.

112. Young RH, Prat J, Scully RE. Ovarian Sertoli-Leydig cell tumors with heterologous elements. I. Gastrointestinal epithelium and carcinoid: a clinicopathologic analysis of thirty-six cases. Cancer 1982; 50: 2448-56

113. Zaloudek C, Norris HJ. Sertoli-Leydig tumors of the ovary. A clinicopathologic study of 64 intermediate and poorly differentiated neoplasms. Am J Surg Pathol 1984; 8: 405-18.

114. Young RH, Scully RE. Ovarian Sertoli-Leydig cell tumors. A clinicopathological analysis of 207 cases. Am J Surg Pathol 1985; 9: $543-69$.

115. Roth LM, Slayton RE, Brady LW, et al. Retiform differentiation in ovarian Sertoli-Leydig cell tumors. A clinicopathologic study of six cases from a Gynecologic Oncology Group study. Cancer 1985; 55: $1093-8$

116. Talerman A. Ovarian Sertoli-Leydig cell tumor (androblastoma) with retiform pattern. A clinicopathologic study. Cancer 1987; 60: 3056-64.

117. Young RH, Scully RE. Ovarian Sertoli-Leydig cell tumors with a retiform pattern: a problem in histopathologic diagnosis. A report of 25 cases. Am J Surg Pathol 1983; 7: 755-71.

118. Aguirre P, Scully RE, DeLellis RA. Ovarian heterologous SertoliLeydig cell tumors with gastrointestinal-type epithelium. An immunohistochemical analysis. Arch Pathol Lab Med 1986; 110: 528-33.

119. Young RH, Perez-Atayde AR, Scully RE. Ovarian Sertoli-Leydig cell tumor with retiform and heterologous components. Report of a case with hepatocytic differentiation and elevated serum alpha-fetoprotein Am J Surg Pathol 1984; 8: 709-18.

120. Oliva E, Alvarez T, Young RH. Sertoli cell tumors of the ovary: clinicopathologic and immunohistochemical study of 54 cases. Am J Surg Pathol 2005; 29: 143-56.

121. Zhao C, Bratthauer GL, Barner R, et al. Comparative analysis of alternative and traditional immunohistochemical markers for the distinction of ovarian sertoli cell tumor from endometrioid tumors and carcinoid tumor: a study of 160 cases. Am J Surg Pathol 2007; 31 $255-66$

122. Zhao C, Bratthauer GL, Barner R, et al. Diagnostic utility of WT1 immunostaining in ovarian sertoli cell tumor. Am J Surg Pathol 2007 31: $1378-86$

123. Busam KJ, Iversen K, Coplan KA, et al. Immunoreactivity for A103, an antibody to melan-A (Mart-1), in adrenocortical and other steroid tumors. Am J Surg Pathol 1998; 22: 57-63.

124. Conlon N, Schultheis AM, Piscuoglio S, et al. A survey of DICER hotspot mutations in ovarian and testicular sex cord-stromal tumors. Mod Pathol 2015; 28: 1603-12.

125. Kato N, Kusumi T, Kamataki A, et al. DICER1 hotspot mutations in ovarian Sertoli-Leydig cell tumors: a potential association with androgenic effects. Hum Pathol 2017; 59: 41-7.

126. Kim MS, Lee SH, Yoo NJ, et al. DICER1 exons 25 and 26 mutation are rare in common human tumours besides Sertoli-Leydig cell tumour. Histopathology 2013; 63: 436-8.

127. Oost EE, Charles A, Choong CS, et al. Ovarian sex cord-stroma tumors in patients with probable or confirmed germline DICER1 mutations. Int J Gynecol Pathol 2015; 34: 266-74.

128. Foulkes WD, Priest JR, Duchaine TF. DICER1: mutations, microRNAs and mechanisms. Nat Rev Cancer 2014; 14: 662-72.

129. Lu J, Getz G, Miska EA, et al. MicroRNA expression profiles classify human cancers. Nature 2005; 435: 834-8 
130. Bahubeshi A, Tischkowitz M, Foulkes WD. miRNA processing and human cancer: DICER1 cuts the mustard. Sci Transl Med 2011; 3: $111-46$.

131. Blenkiron C, Goldstein LD, Thorne NP, et al. MicroRNA expression profiling of human breast cancer identifies new markers of tumor subtype. Genome Biol 2007; 8: R214.

132. Grelier G, Voirin N, Ay AS, et al. Prognostic value of Dicer expression in human breast cancers and association with the mesenchyma phenotype. Br J Cancer 2009; 101: 673-83.

133. Karube $\mathrm{Y}$, Tanaka H, Osada $\mathrm{H}$, et al. Reduced expression of Dicer associated with poor prognosis in lung cancer patients. Cancer $\mathrm{Sci}$ 2005; 96: 111-5.

134. Merritt WM, Lin YG, Han LY, et al. Dicer, Drosha, and outcomes in patients with ovarian cancer. $N$ Engl J Med 2008; 359: 2641-50.

135. Lambertz I, Nittner D, Mestdagh P, et al. Monoallelic but not biallelic loss of Dicer1 promotes tumorigenesis in vivo. Cell Death Differ 2010; 17: $633-41$.

136. Kumar MS, Pester RE, Chen CY, et al. Dicer1 functions as a haploinsufficient tumor suppressor. Genes Dev 2009; 23: 2700-4.

137. de Boer CM, Eini R, Gillis AM, et al. DICER1 RNase IIIb domain mutations are infrequent in testicular germ cell tumours. BMC Res Notes 2012; 5: 569.

138. Hill DA, Ivanovich J, Priest JR, et al. DICER1 mutations in familial pleuropulmonary blastoma. Science 2009; 325: 965.
139. Choong CS, Priest JR, Foulkes WD. Exploring the endocrine manifestations of DICER1 mutations. Trends Mol Med 2012; 18: 503-5.

140. Foulkes WD, Bahubeshi A, Hamel N, et al. Extending the phenotypes associated with DICER1 mutations. Hum Mutat 2011; 32: 1381-4.

141. Rio Frio T, Bahubeshi A, Kanellopoulou C, et al. DICER1 mutation in familial multinodular goiter with and without ovarian Sertoli-Leydig cell tumors. JAMA 2011; 305: 68-77.

142. Slade I, Bacchelli C, Davies H, et al. DICER1 syndrome: clarifying the diagnosis, clinical features and management implications of a pleiotropic tumour predisposition syndrome. J Med Genet 2011; 48: 273-8.

143. Schultz KA, Pacheco MC, Yang J, et al. Ovarian sex cord-stromal tumors, pleuropulmonary blastoma and DICER1 mutations: a report from the International Pleuropulmonary Blastoma Registry. Gynecol Oncol 2011; 122: 246-50.

144. Akman L, Ertas IE, Gokcu M, et al. Ovarian sertoli-leydig cell tumors: a multicenter long-term clinicopathological analysis of 27 patients. J Cancer Res Ther 2016; 12: 290-4.

145. Gui T, Cao D, Shen K, et al. A clinicopathological analysis of 40 cases of ovarian Sertoli-Leydig cell tumors. Gynecol Oncol 2012; 127: $384-9$.

146. Sigismondi C, Gadducci A, Lorusso D, et al. Ovarian Sertoli-Leydig cell tumors. A retrospective MITO study. Gynecol Oncol 2012; 125: $673-6$ 